УДК $78.03+786.2$

\author{
Чжуу Сяоле, \\ здобувач кафедри історії музики та музичної етнографії \\ Одеської національної музичної \\ академії імені А. В. Нежданової

\section{ПОЗАМУЗИЧНІ ЧИННИКИ В ІНСТРУМЕНТАЛЬНИХ ТВОРАХ Ф. ЛІСТА (НА ПРИКЛАДІ «ПЕРШОГО РОКУ МАНДРІВ»)}

\begin{abstract}
Мета роботи. Стаття виявляє роль позамузичних чинників у творчому методі Ф. Ліста на матеріалі програмної інструментальної музики композитора. Методологія роботи грунтується на методі комплексного дослідження з використанням даних музикознавства, літературознавства, філософії та культурологіі, що спрямоване на виявлення глибинного зв'язку музичного твору з поетичним джерелом в ракурсі сучасної теорії синестезії. Наукова новизна роботи полягає у визначенні ролі та значення поетичного слова в нотних текстах інструментальних творів Ліста та у розширенні уявлень про дію позамузичних чинників в інструментальній музиці. Висновки. Авторське слово композитора (власне або цитоване), виведене в нотному тексті, оформлене як епіграф або заголовок, виступає невід'ємним смисловим чинником музичного тексту, иілісної «програми дї», творчого зусилля виконавия і виявляється ключовим фактором в його інтерпретації, прояснює і дає можливість уточнити ідеї оригінального звукового та філософсько-естетичного світів композитора.
\end{abstract}

Ключові слова: $Ф$. Ліст, романтизм, позамузичні чинники, епіграф, взаємодія і синтез мистецтв, синестезія, програмна інструментальна музика.

Zhu Xiaole, The Odessa National A. V. Nezhdanova Academy of Music, applicant of the department of history of music and musical ethnography

Non-Musical factors in instrumental works by $F$. Liszt (on the example of "The First Year of the Wanderings»)

Objective. The article reveals the role of non-musical factors in F. Liszt's creative method on the basis of the programme instrumental music of the composer. The methodology of the work is based on the method of complex research using the data of musicology, literary criticism, philosophy and culturology, which helps to reveal the deep connection of the musical work with the poetic source in the perspective of the modern theory of synaesthesia. The scientific novelty of the work is to determine the role and significance of the poetic word in the sheet music of Liszt's instrumental works and to expand the notions of the effect of non-musical factors in instrumental music. Conclusions. The author's word of the composer (actually or cited), derived in the musical text, drawn up

(C) Чжу Сяоле, 2016 
as an epigraph or title, acts as an inalienable semantic factor of the musical text, a holistic «program of action,» the creative efforts of the performer, and is a key factor in its interpretation, clarifies and gives the opportunity to clarify the ideas of the original sound and philosophical-aesthetic composer's worlds.

Keywords: F. List, Romanticism, non-musical factors, epigraph, interaction and synthesis of arts, synaesthesia, programme instrumental music.

Чжу Сяоле, соискатель Одесской национальной музыкальной академии им. А. В. Неждановой

Внемузыкальные факторы в инструментальных произведениях Ф. Листа (на примере «Первого года странствий»)

Цель работы. Статья выявляет роль внемузыкальных факторов в творческом методе Ф. Листа на материале программной инструментальной музыки композитора. Методология работы основывается на методе комплексного исследования с использованием данных музыковедения, литературоведения, философии и культурологии, что способствует выявлению глубинной связи музыкального произведения с поэтическим источником в ракурсе современной теории синестезии. Научная новизна работы заключается в определении роли и значения поэтического слова в нотных текстах инструментальных произведений Листа и в расширении представлений о действии внемузыкальных факторов в инструментальной музыке. Выводы. Авторское слово композитора (собственное или цитируемое), выведенное в нотном тексте, оформленное в качестве эпиграфа или заголовка, выступает неотбемлемой смысловой составляющей музыкального текста, целостной «программы действия», творческого усилия исполнителя и оказывается ключевым фактором в его интерпретации, проясняет и уточняет идеи оригинального звукового и философско-эстетического миров композитора.

Ключевые слова: Ф. Лист, романтизм, внемузыкальные факторы, эпиграф, взаимодействие и синтез искусств, синестезия, программная инструментальная музыка.

Актуальність теми роботи. Для романтичної музики позамузичні фактори, передусім слово, постали не тільки специфічним чинником вокально-інструментальної цілісності, але й невід'ємним компонентом явища романтичної інструментальної програмності. Недаремно майже усі композитори романтичної епохи прославилися своїми поетично-літературними, критично-музикознавчими, педагогічними текстами - поряд з музичними, які не тільки і не стільки оцінювали окремі твори і творчість авторів, скільки обговорювали можливості та специфічні засоби впливу музики, ії предметного змісту та естетичного призначення. У цьому сенсі літературно-критичні опуси романтиків (як і подальших композиторських поколінь) містять передумови 
розуміння їх ставлення до музичного задуму і логіки його композиційного втілення, зближуються з літературно-поетичними факторами програмності. Отже, важливими стимулами розвитку музичної програмності виступають позамузичні компоненти, а програма в музиці конкретизує зміст твору, повідомляючи слухачеві про такі його елементи, які автор спеціально (і специфічно) наголошує. При зростанні ролі програмності пишно проростають у романтиків поетичні епіграфи; складні, сюжетно, картинно, суб'єктивно-психологічно оформлені заголовки (які співвідносяться з відповідними видами програмності за Ю. Хохловим [19] та Ю. Тюліним [18]). Ф. Ліст як яскравіший, «ідеально повний» представник композиторського типу центрального періоду романтизму в даній галузі також відзначений значним внеском, пролонгованим у композиторських прийомах наступних поколінь аж до XX століття. Отже виявлення ролі «невидимого» (не обов'язково проголошеного для слухачів і навіть не надрукованого в нотному тексті, як це відбулося з подальшими виданнями нот «Років мандрів» Ф. Ліста) вербального компонента його інструментальної програмної музики є актуальним для музикознавчих і теоретично-виконавських досліджень, що і виступає метою даної статті.

Викладення основного матеріалу. За визначенням О. Соколова, «програмною слід вважати інструментальну музику, яка має подане авторське слово, що несе доповнюючо-конкретизуючу функцію» [15]. За зауваженням В. Конен щодо романтичної доби, «програма була одночасно і творчою опорою для самого композитора, і дороговказом для необізнаного слухача» [7, 23]. Примітно, що програмні жанри часто ставали провідниками нових ідей, в той час як усталені образи та інтонації епохи знаходили художнє узагальнення у сфері чистої музики. Розкриваючи виконавцеві-читачеві (а можливо, й публіці) «горизонти музичної душі своїх авторів», композиторські та запозичені літературно-поетичні тексти-програми як «особливого роду музично-культурологічні артефакти являють собою не менш насичену область наукового (і практично-виконавського, інтерпретаторського. - Ч. С.) пошуку, ніж тексти музичні» [14, 86-87]. Таке авторське слово композитора (у тому числі цитоване), виведене в нотному тексті, оформлене як епіграф або заголовок, виступає невід'ємним смисловим чинником музичного тексту, цілісної «програми дії», творчого зусилля виконавця і найчастіше виявляється ключовим фактором в його інтерпретації, прояснює і дає можливість уточнити ідеї оригінального звукового та філософсько-естетичного світів композитора. 
Тобто така «програма дії» програмується смисловим завданням, яке в мистецтві має естетичну спрямованість, - жанрово-естетичними та ідейно-стильовими тенденціями художньої творчості. У музиці такі тенденції обумовлені участю позамузичних компонентів (що з них, власне, випливають стимули програмності), з яких найважливішим виступає літературно-поетично оформлене слово у розгортанні специфічно музичної композиції, тобто програмністю в традиційному вузькому значенні цього поняття (мається на увазі слово, не покладене на музику у вокально-інструментальній цілісності, а спрямоване на створення, уточнення загальної авторської ідеї-концепції). Таке авторське слово композитора в певних випадках постає «єдиним працюючим ключовим кодом побудови звучної моделі музичного твору» $[14,87]$. I хоча «переклад на мову наших понять, на мову людини, це абстракція, редукція до пізнаваного, втрата найголовнішого мови світу, який повинен залишатися незрозумілим, повинен лише відчуватися» (А. Шенберг $[21,25])$, в даному випадку вербальний «доданок» є суттєвим і невід'ємним компонентом програмного замислу, концептуальної - глобальної цілісності твору. Глобальна зв'язність, на відміну від локальної, характеризує текст в цілому або великі його фрагменти і користується поняттями, «які включають топік, тему, загальний зміст, основний зміст» [20]. У такому сенсі саме глобальна зв'язність «веде до актуалізації епіграфа як висловлювання в тексті» [20] і кореспондує з романтичним «синтезом мистецтв», з проголошеною Ф. Лістом тезою про «оновлення музики шляхом її внутрішнього зв'язку з поезією» $[11,71]$. На цілісність виконавського образу у трактуванні Ліста-піаніста на основі «вживання» у твір вказує Мільштейн: «головне - не тільки почути і зрозуміти те, що хотів сказати автор, але й відчути, оживити почуте, тобто зробити музичний твір своїм особистим надбанням, виконувати його як свій власний... особистість (Ліста. - Ч. С.) і особистість виконуваного їм автора на деякий час немов би гармонійно зливаються. При цьому він трактує твір переважно синтетично, як єдиний живий організм», не «розчленовуючи на окремі виразові елементи» і не засновуючи виконання «на спекулятивному, відірваному від почуттів міркуванні про ідею» [11, 71-72]. Так само і композиторська творчість митця неможлива поза поетичних уявлень: «Програмна «поемність» була для нього як артиста природною необхідністю» [там само]. А як композитор, обізнаний у тонкощах виконавства, Ліст прагне максимально донести до виконавця свого твору «який спосіб, яка сцена, який ландшафт пред- 
ставлялися композитору, яке почуття володіло ним, коли він творив, з якого джерела народилися скорбота чи радість, висловлені ним у звуках» [цит. за 11, 72]. Саме таку пояснювальну, уточнюючу функцію несуть епіграфи (окрім розгорнутих заголовків) до кожної п’єси «Років мандрів».

Епіграф був неодмінним елементом романтичної літературної поеми ${ }^{1}$, даючи поетові можливість передрікати головні події, відбивати «душевний стан героя в кульмінаційний момент або ставлення автора до того, що буде відбуватися», «вибудувати тимчасову перспективу поеми: зв'язати минуле і сьогодення», «наповнити рядки глибоко особистим змістом», відображати структуру поеми (підтекстовою інформацією), виявити насиченість у змістовному та «підтекстовому» планах [8], тобто «кодування смислу» [12]. У плинному процесі романтичного «синтезу мистецтв» літературне слово й літературно-поетичні прийоми (як то епіграф) не могли не відбитися на музичних виразових (програмних) засобах.

О. Цуканова доводить статус епіграфа як частини тексту (літературного), спираючись на комплексний підхід у сучасній теорії інтертекстуальності. Остання передбачає «включення одного тексту в інший, пов'язуючи тексти різних епох, різномовні тексти і тексти різних жанрів» [20]. В рамках теорії інтертекстуальності епіграф, як включення одного тексту в інший, розуміється як «чужа мова» (Бахтін), «інтертекст» (Крістєва; Смирнов), «прецедентний текст» (Караулов), «інтекст» (Тороп), «текст у тексті» (Лотман) [там само]. М. Бахтін, один з основоположників теорії інтертекстуальності, пояснює це так: «...чим інтенсивніше, диференційованіше і вище соціальне життя, тим більшу питому вагу серед предметів мови отримує чуже слово, чуже висловлювання, як предмет зацікавленої передачі, тлумачення, обговорення, оцінки, спростування, підтримки, подальшого розвитку і т. п.» $[2,150]$. У той же час при цілісному розгляді твору епіграф виступає елементом авторського тексту. Як інтертекстуальна одиниця він «провокує створення естетичної напруги «своє - чуже», де «своє» засноване на «чужому» шляхом залучення до «свого» «чужого», і тоді «чуже» стає «своїм»» $[17,56]$. Сутність «чужого слова» М. Бахтін пояснює як неодмінну умову процесу породження будь-якого тексту,

\footnotetext{
${ }^{1}$ Перші епіграфи в літературі зафіксовані наприкінці XV століття (наскільки відомо, в книзі «Хроніки» Ж. Фруссара - написана в 1404, опублікована в 1495 , «Calendarium» Реджомонтано - Венеція, опубл. близько 1476), проте найбільшого поширення набули тільки з кінця XVIII - початку XIX століть.
} 
тобто в глобальному розумінні. Послідовники бахтінського вчення з точки зору теорії інтертекстуальності вбачають тут «макротекстовий» характер прийомів художнього тексту. У сучасному науковому дискурсі текст трактується двояко: як конкретна форма фіксації твору (нотно-знаковий запис композитором) та як такий, що створюється під час смислотворної виконавської інтерпретації. С. Лисенко визначає інтерпретуємий текст як «поліструктурне семіотичне утворення, яке крім поверхневого (знакового) рівня має глибинний смисл, що осягається в процесі розуміння тексту і породжується творчою свідомістю» виконавця $[10,15]$. Саме тут під час виконавської інтерпретації (а епіграфи аналізуємого твору Ліста й адресовані, перш за все, виконавцеві - вони не позначені в сучасних нотних виданнях «Років» і звичайно не проголошуються на концерті) для виявлення глибинних механізмів смислопородження оптимальним здається синестетичний підхід, як «асоціативний механізм, що бере участь у формуванні невербальних смислів на стику рядів синтетичного тексту» (Н. Коляденко [6]). За таких умов «гра смислами, текстовими кодами... одночасно стає засобом активного залучення реципієнтів до діалогу, до художньо-асоціативної інтертекстуальної співтворчості, що дозволяє виявити непомічені раніше смислові можливості» твору $[10,16]$. У лістівських «Роках мандрів» «чуже» виступає не тільки в авторському, а й у жанрово-видовому розумінні - слово/музика, тобто відбувається саме синестетичний мистецький акт.

Однак слід відокремлювати жанрово-семантичний статус епіграфа як частини художнього тексту (О. Цуканова) музичного-інструментального твору від слова (вербального компонента) у так званих синтетичних «сукупних» жанрах (А. Сохор $[16,59])$ - опері, музичнодраматичному театральному творі, ораторії тощо. Виразове завдання музичної сторони $є$ «безпосереднім впливом на емоційну сферу людини з метою виклику відповідної реакції. Оскільки вона розкривається на рівні широких предметних узагальнень, то ії значимість нерідко в такій структурі стає домінуючою» $[1,8]$, тобто тут в синтетичній структурі використовуються домінантні семантичні відмінності знакових систем музики та слова. У випадку програмного інструментального твору з літературно-поетичним епіграфом останній не підкорюється, але й не домінує у художньому тексті, а виступає, скоріше, художнім програмним контекстом, фіксуючи синестетичну природу виконавського і композиторського мислення. В цьому ракурсі Ліст виступає великим новатором, випередившим свою епоху - актуалізація сине- 
стетичності, як ефективного засобу, коригуючого раціонально-логічні настанови мислення, відбулася вже на теренах постмордернової естетики (хоча коріння синестетичної природи художньої свідомості - античні $[9,628])$. Б. Галєєв переконливо довів, що у всіх своїх різновидах «синестезія - це «міжчуттєва» асоціація» $[3,15]$, в основі якої - смисл, значення, «єдиний художній задум» [там само, 55], а не примарно вгадувана, точна, раз і назавжди дана відповідність (наприклад, певної тональності -конкретному кольору). Саме таку функцію долучення (й додатку «ззовні», «чужими» знаками-словами) до єдиного смислу виконує літературно-поетичний епіграф в інструментально-програмній семантиці творів Ліста. На думку К. Зенкіна, «романтичну тенденцію синтезу мистецтв має сенс розглядати як особливий випадок прагнення до ще більш глибокого синтезу - відчувати музику в єдності з найвищими духовними началами» [5].

Практично для всіх своїх програмних симфонічних поем Ліст сам створив прозаїчні епіграфи-передмови. Більшість фортепіанних творів Ліста мають літературні за джерелом епіграфи, запозичені з творів сучасників-романтиків або з антологій кращих взірців класики (а також - скульптурні, живописні - у «Другому році мандрів»; композитору ніби недостатньо одного виду мистецтва у бажанні точніше вказати виконавцеві поетичні підоснови твору, «пробудити його образне мислення» $[11,73])$. У дев'ятичастинному «Першому році мандрів» (остаточна редакція - 1855p. - після переробки циклу «Альбом мандрівника» по враженнях з подорожі з Марією д’Агу по Швейцарії та Італії від 1835 р.) окрім програмних заголовків майже кожній п’єсі композитор додає поетичного епіграфа, переважно з третьої пісні «Паломництва Чайльд-Гарольда» Байрона (саме до цього «культового» романтичного автора йдуть витоки Лістівського задуму - точний переклад лістівського твору «Роки паломництва»), також - 3 віршів Й. Шиллера, прозаїчних текстів роману Е. Синанкура. Характерно, що відповідно до свідомого посилу «синтезу мистецтв», понадуважного втілення своїх програмних задумів, обкладинка кожної п'єси (першому виданні), крім вказаних поетичних епіграфів, цитат, цілих витягів з літературних творів, містила малюнок, спеціально виконаний художником Кречмером (у сучасних нотних виданнях «Років» усього цього частіше немає).

«Перший рік мандрів», як відомо, символізує Природу - важливий знак романтиків (Другий і Третій - Мистецтво та Релігію відповідно, як стадії духовного піднесення митця). Багатогранна Природа 
подається з декількох боків [4, 205], а музичні образи народжуються у синестезії почуттів. Перший тип представлений п'єсами, пов'язаними 3 чарівними замальовками альпійських краєвидів, які, на перший погляд, надихають безтурботність і спокій, природа ніби вабить, заколисує. Так, байронівський (їх у циклі більшість) епіграф до п’єси «На Валенштадському озері» (№ 2) - «...лладь озера! Простор твой тихоструйный, / столь чуждый шума - словно шепчет мне, / что должен я уйти от жизни бурной, / от мутных волн - к прозрачной глубине» ${ }^{1}$ з закладеною картинністю відчутно відсилає піаніста до останніх рядків, коли пейзажна картинність перетворюється на психологізовану мораль, звернену до внутрішнього світу людини, «прозорої глибини» іiї духовності. Виконавцю необхідно відтворити ці грані - від зовнішньої краси природи, де людина не завжди відповідає їй своєю внутрішньою красою. Стриманий прозорий супровід, барвисті гармонії ніби малюють широкі далі, народжують звукову й навіть оптичну перспективу, але світла мелодія у високому регістрі мета, до якої необхідно долучатися. Психологічні параметри піанізму мають бути втіленими за рахунок якостей фортепіанного звуку, туше, багатомірності фактури. «Женевським дзвонам» (№ 9) знову передує Байрон - «...полночь спала, озеро было / спокойно, небеса покрыты звездами / мы плыли вдали от берега /. / я больше не живу в себе самом, - / я часть того, что вижу». Маємо ту саму трансформацію від картинності до психологізму у прагненні душевного спокою вдалі від суєтного життя не «на природі». Ноктюрнове коливання 6/8 на легких хвилях чистого гірського озера; альпійське розряджене повітря, в якому далеко розносяться дзвінкі удари дзвонів-пасажів і дзвонів-акордів. Образ церковних дзвонів притягнутий недаремно - адже тільки у поверненні до Бога можна знайти жаданий спокій (нагадаємо, що кінцева редакція «Першого року» відбулась вже у 1855 році). Ноктюрну «У джерела» (№ 4) передпосланий текст Й. Шиллера - «В шелестящей прохладе / начинаются игры / юной натуры». Грайливо-скерцозні пасажі з «легкими» стакатними басами, постійними композиторськими ремарками «tranquilli», «dolcissimo», «brillante», «dolce e grazioso», демонструючі гру води (природи) і юних красунь (людини), що відчувають свою привабливість, молодість, енергію, - знову гра замальовок та психологічних станів. Але від виконавця тут вимагається справжня майстерність фортепіанної техніки і технології звуковидобування.

\footnotetext{
${ }^{1}$ Усі тексти епіграфів цитуються за роботою В. Петрова [13].
} 
Дещо інший, але близький «замальовкам» тип програмних п'єс пов'язаний з красотою простоти життя на природі (пастухів в горах) з неодмінною паралеллю до внутрішнього світу героя («Пастораль» - № 3, «Еклога» або «Чайльд Гарольд» - № 7, «Туга за батьківщиною» - № 8). У цих п’єсах задіяні хороводні наспіви, веселі (№ 7) та сумні (№ 8) пастуші награвання, супроводжувані гудінням волинки (Ліст використовує справжні швейцарські наспіви). «Еклога» або «Чайльд Гарольд» має байронівське поетичне передування - «Встает заря, и цвет ее ланит / росистым благовонием овеян, / И облаков улыбка мир живит /.../ Проснулась жизнь, и ею вновь одеян / горящий день» - з радісними награшами. Але авторські ремарки «dolce», «grazioso», «sempre dolce» вимагають постійної виконавської уваги 3 точки зору фортепіанного звуковедення у паралель до пастушого духового інструмента. У п’єсі «Туга за батьківщиною» (№ 8, відразу після веселого награшу) привнесений досить великий прозаїчний (але поетизований) текст Е. Сенанкура: «Я ніколи не бачив картини Альп, яка б так їх висловлювала, як справжня альпійська пісня. Пісня пастухів не тільки викликає спогади, вона малює, перші ж звуки ії переносять вас у полонини, неподалік гірських рудувато-сірих скель, під холодне небо і пекуче сонце. Ви на вершині округлих пагорбів, вкритих пасовищами. Ви переймаєтеся повільністю оточуючих речей $\mathrm{i}$ величчю місцевості» (Е. Сенанкур. Лист Обермана «Про романтичне висловлювання і пастуші пісні»). Ця надзвичайно поетична сторінка «Мандрів» - своєрідна лірична вершина циклу з імпровізаційно забарвленими змінами темпів і тональностей, емоційними сплесками та «зависаннями», присутність інтонації збільшеної секунди спрямовує виконавця до національно-особистого. Окрім відповідності поетичному образу піаністично-звукового наповнення потребується композиційна цілісність викладу.

Інша група п’єс («Часовня Вільгельма Телля» - № 1, «Гроза»№ 5) виказує суперечливий характер природи й внутрішнього світу героя у їх цілісності (номери мають свою симетрію розташування серед пасторальних, грайливих, ліричних). Це бурхливо-бунтівні, героїчні п’єси з відповідними «фірмовими» лістівськими музично-інструментальними засобами - потужними, повнозвучними акордами, октавними пасажами, рояльними (оркестровоподібними) тремоляндо і вібрато, тріольно-дуольною поліритмією, енергійним пунктирним ритмом, чергуванням рук у акордах, найшвидшими темпами. У «Часовні Вільгельма Телля» Ліст використовує у якості епіграфа 
девіз швейцарських повстанців у національно-визвольній боротьбі: «Один за всіх, усі за одного». Підкреслимо, що це перша п’єса циклу, і вона співзвучна угорським настроям тої пори. Лаконізм самого епіграфа тільки підкреслює рішучість Героя. № 5 - «Гроза» - перегукується з № 1 і має байронівський епіграф: «Где ваш предел, о бури? Ваши ль стоны / звучат порой в сердечной глубине? / Иль ваши, как орлов, жилища в вышине?». А амплітуда Горнього/Низького - $з$ регістровим «розмахом» фортепіанно-«оркестрової» фактури, міцна сила проявлень духу - з силою природної бурі - міццю концертного рояля Ліста та усього його героїчного обліку.

№ 6 - «Долина Обермана» - найвідоміша центральна п’єса циклу. Вона займає й особливе місце у загальній драматургії та у власному, специфічному уособленні романтичної «цілісності протиріч», а також має величезний навіть для Ліста епіграф. Твір опрацьовує типовий образ доби романтизму - «суперечливий внутрішній світ «молодого чоловіка XIX століття», його вічні сумніви, коливання і пристрасні пориви... нескінченні трансформації, здійснені з властивою Лісту майстерністю, передають мінливі душевні настрої героя - від безнадійного смутку до екстатичних поривів» [4, 206]. За вказівкою М. Друскіна, «скорботна низхідна мелодія, з зітханнями і протяжними затриманнями, стала свого роду «інтонацією епохи» для втілення елегійних образів» [там само]. Її суперечливі настрої натхненні відразу двома позамузичними джерелами - романом в листах французького письменника першої половини XIX століття Е. Сенанкура і строфою з «Паломництва Чайльд-Гарольда» Байрона. Отже в епіграфі поєднується наступна послідовність літературно-поетичних (Лісту ніби не вистачає однієї фрази або автора) цитат. Спочатку в рамках одного об'ємного епіграфа виступають два прозових тексти роману «Оберман. Листи, видані Сенанкуром» Е. П. Сенанкура: «Чого я чекаю? Чим я є? Про що запитувати природу? Кожна причина невловима, кожен фінал оманливий, всяка форма мінлива, повсякчас вичерпується... я відчуваю, що я існую, щоб виснажувати себе в неприборканих бажаннях, щоб насититися спокусами фактичного світу, щоб залишитися приголомшеним його сповненими млістю оман» (Сенанкур, Лист Обермана № 53), «Невимовна чутливість, чарівність і мука наших суєтних років, широке усвідомлення природи - всюди тяжкої і всюди незбагненної, всесвітня пристрасть, байдужість, запізніла мудрість, солодке самозабуття; всі потреби і глибока туга, які може таїти в собі серце смертного - все це я пізнав, все випро- 
бував в цю незабутню ніч. Я зробив зловісний крок назустріч порі старезності; я марно витратив десять років мого життя» (Сенанкур, Лист Обермана № 4). Далі у нескінченних сумнівах Ліст додає ще дев’ятирядковий фрагмент з Байрона: «О, если бы нашел я воплощенье / и выразил хотя б не все, хоть часть / того, что значит чувство, увлеченье, / дух, сердце, разум, слабость, сила, страсть, / и если б это все могло совпасть / в едином слове «молния» и властно / сказало бы, что жизнь дана мне власть, - / о, я б заговорил! - Но ждать напрасно!/ Как скрытый в ножнах меч, зачахнет мысль безгласно». У цій п’єсі концентруються духовно-філософські, суто романтичні суперечливі осягання цілісності буття як єдності Природи, людської індивідуальності, мистецтва, загальнолюдських цінностей земного та надземного порядку.

Висновки. На основі аналізу романтичної музичної поетики та поетичності лістівського фортепіанного циклу можна стверджувати, що поетичний (літературний) епіграф, спрямовуючи, глобалізуючи семантичну конструкцію авторського тексту програмного інструментального твору, виступає специфічною рисою інструментальної програмності Ф. Ліста, що стверджує синестетичний характер мислення й світовідчуття митця (від невіддільності життєвого шляху до творчості, до універсальності мислення, «енциклопедичних» знань в різних областях мистецтва та музичних специфікацій). Авторське слово композитора (власне або цитоване), виведене в нотному тексті, оформлене як епіграф або заголовок, виступає невід'ємним смисловим чинником музичного тексту, цілісної «програми дії», творчого зусилля виконавця і виявляється ключовим фактором в його інтерпретації, прояснює і дає можливість уточнити ідеї оригінального звукового та філософсько-естетичного світів композитора, сприяючи глибинним механізмам смислоутворення у виконавській інтерпретації.

\section{СПИСОК ЛІТЕРАТУРИ}

1. Алексеева М. В. Музыка и слово: проблема синтеза в эстетической теории и художественной практике: дис. ... канд. филос. наук: 09.00.04 / Рос. гос. ун-т туризма и сервиса. Москва, 2010. 164 с.: ил.

2. Бахтин М. М. Проблемы содержания, материала и формы в словесном. Вопросы литературы и эстетики. М.: Наука. 1975. 327 с.

3. Галеев Б. Содружество чувств и синтез искусств. М.: Знание, 1982.63 с.

4. Друскин М. История зарубежной музыки. Изд. шестое. М.: Музыка, 1983. Вып. 4: Вторая половина XIX века. 528 с. 
5. Зенкин К. Слово в фортепианных произведениях Листа. Ференц Лист и проблемы синтеза искусств. Харьков: Каравелла, 2002. DOI: : http://hansburg. narod.ru/lizstzenk.htm

6. Коляденко, Н. П. Синестетичность музыкально-художественного сознания (на материале искусства XX века). Новосибирск, 2005. 392 с.

7. Конен В. Этюды о зарубежной музыке. М. - Л., 1975. 480 с.

8. Кощиенко И. В. Полифункциональность эпиграфа в творчестве А. С. Пушкина: дис.... канд. филол. наук: 10.01 .01 / Ин-т рус. литературы Рос. акад. наук. Санкт-Петербург, 2004. 249 с.

9. Лосев А. Аристотель и поздняя классика. История античной эстетики. М.: Фолио, 2000. 880 c.

10. Лысенко С. Синтетический художественный текст как феномен интерпретации в музыкальном театре: автореф. дис. ... д-ра искусств.: 17.00.02 / Новосиб. гос. консерватория (академия) имени М. И. Глинки. Новосибирск, 2014. $46 \mathrm{c}$.

11. Мильштейн Я. Ф. Лист. М.: Музыка, 1970. Т. 2. 600 с.

12. Николаев В. А. Шопен-педагог и его значение в истории фортепианного искусства: автореф. дис. ... канд. искусствовед.: 17.00.02 / Гос. музык.пед. ин-т. Москва, 1989. 21 с.

13. Петров В. Светские тексты как основа эпиграфа в партитурах инструментальных произведений. Вестник КГУ. 2016. № 1. С. 115-119.

14. Рынденко О. В. Авторские комментарии и ремарки как культурный феномен в фортепианном творчестве Оливье Мессиана: 17.00.03 / Нац. муз. акад. Украины им. П. И. Чайковского. Киев, 2010. 176 с.

15. Соколов О. В. Морфологическая система музыки и ее художественные жанры. Нижний Новгород : Изд-во Нижегор. ун-та, 1994. 215 с.

16. Сохор А. Музыка как вид искусства. Статьи, исследования. М., 1978. $328 \mathrm{c}$.

17. Трепачко А. Н. «Чужая речь» в творчестве Давида Самойлова: дис.... канд. филол. наук: 10.01.01 / Ставропольс. гос. ун-т. Ставрополь, 2004. 177 с.

18. Тюлин Ю. Н. О программности в произведениях Шопена. М.: Госмузиздат, $1963.55 \mathrm{c}$.

19. Хохлов Ю. Н. О музыкальной программности. М.: Гос- музиздат, 1963. $144 \mathrm{c}$.

20. Цуканова Е. М. Семантическая связь эпиграфа с текстом: дис. ... канд. филол. наук: 10.02.01, 10.02.19 / Орловс. гос. ун-т. Орел, 2003160 с.

21. Шенберг А. Стиль и мысль. Статьи и материалы. М.: Композитор, 2006. $528 \mathrm{c}$.

\section{REFERENCES}

1. Alekseeva, M. V. (2010). Music and the word: the problem of synthesis in aesthetic theory and artistic practice: Extended abstract of candidate's thesis. Moscow: RGUTiS [in Russian]. 
2. Bakhtin? M. M. (1975). Problems of content, material and form in verbal. Questions of literature and aesthetics. Moscow: Science [in Russian].

3. Galeev, B. (1982). Commonwealth of the senses and the synthesis of the arts. Moscow: Knowledge [in Russian].

4. Druskin, M. (1983). History of foreign music. Issue. 4. M.: Music [in Russian].

5. Zenkin, K. (2002). The word in the piano works of Liszt. Ferenc Liszt and problems of synthesis of arts. Kharkov: Caravel,. Retrieved from : http://hansburg. narod.ru/lizstzenk.htm [in Russian]

6. Kolyadenko, N. P. (2005). Synesthetic music and artistic consciousness (based on art of the twentieth century). Novosibirsk [in Russian].

7. Konen, V. (1975). Etudes about foreign music. Moscow-Leningrad [in Russian].

8. Koschienko, I. V. (2004). Polyfunctionality of the epigraph in the works of Alexander Pushkin. Candidate's thesis St. Petersburg: IRL [in Russian]

9. Losev, A. (2000). Aristotle and the late classics. The history of ancient aesthetics. M.: Folio [in Russian]

10. Lysenko, S. (2014). Synthetic artistic text as a phenomenon of interpretation in the musical theater. Doctor's thesis. Novosibirsk: NGK. [in Russian].

11. Milstein, Ya.F. (1970). Sheet. Moscow: Music. [in Russian].

12. Nikolaev, V. A. (1989). Chopin-educator and its importance in the history of piano art. Extended abstract of candidate's thesis. Moscow: GMPI [in Russian].

13. Petrov, V. (2016). Secular texts as the basis of the epigraph in the score of instrumental works. Bulletin of KGU.№ 1 [in Russian].

14. Ryndenko, O. V. (2010). Author's comments and remarks as a cultural phenomenon in the piano work of Olivier Messiaen. Extended abstract of candidate's thesis. Kiev: NMAU named after. P. I. Tchaikovsky [in Ukrainian].

15. Sokolov, O. V. (1994). Morphological system of music and its artistic genres. Nizhny Novgorod [in Russian]..

16. Sohor, A. (1978). Music as an art form. Articles, research. Moscow [in Russian]

17. Trepachko, A. N. (2004). «Another's speech» in the work of David Samoilov. Candidate's thesis. Stavropol: StavGU [in Russian].

18. Tyulin, Yu.N. (1963). On the program in the works of Chopin. Moscow: State Publishing House [in Russian].

19. Khokhlov, Yu.N. (1963). About musical programming. Moscow: State Publishing House,. [in Russian].

20. Tsukanova, E. M. (2003). Semantic connection of the epigraph with the text. Candidate's thesis. Orel: OSU [in Russian].

21. Schoenberg, A. (2006). Style and thought. Articles and materials. M.: Composer [in Russian].

Стаття надійшла до редакції 15.06.2016

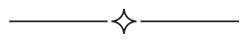

